\title{
KEBIJAKAN PEMERINTAH DALAM BIDANG PENDIDIKAN DARI ORDE LAMA SAMPAI ORDE BARU (Suatu Tinjauan Historis)
}

\author{
As'ad Muzammil \\ Sekolah Tinggi Agama Islam Negeri Jurai Siwo Metro Lampung Indonesia \\ Email: asad.muzammil@gmail.com
}

\begin{abstract}
Map of political Islam in Indonesia is always colored by the government political map. From the pre-independence era, the post-independence (old order), the new order and the reform era. Islamic education is still in a position that is generally not in favor of the empowerment of the people. Education is a tool for which the government used it to escort people and people to the desired political objectives, theoretically it is not wrong if the government wants the product graduate of educational institutions contribute to development. But at the same time the government should also give freedom to the world of education to determine its direction with permanent gets assistance, support, and facilitation from the government.
\end{abstract}

Keywords: government policies, Islamic education, people empowerment

\section{A. Pendahuluan}

Pendidikan adalah memanusiakan manusia muda. Jadi pendidikan tersebut dilakukan oleh manusia (dewasa) dengan upaya yang sungguh-sungguh serta strategi dan siasat yang tepat demi keberhasilan pendidikan tersebut. Pelaksanaan pendidikan berlangsung dalam keluarga sebagai pendidikan informal, di sekolah sebagai pendidikan formal dan di masyarakat sebagai pendidikan nonformal serta berlangsung seumur hidup.

Penyelenggaraan pendidikan, selain dilakukan oleh masyarakat sendiri, juga dilakukan oleh pemerintah, atau sekurang-kurangnya mendapatkan bantuan dari pemerintah. Pendidikan yang mendapatkan bantuan dari pemerintah ini pada akhirnya terjadi proses saling mempengaruhi. Dari satu sisi situasi pemerintahan dipengaruhi oleh corak dari lulusan pendidikan, dan pada sisi lain pemerintah juga mempengaruhi 
dunia pendidikan. Corak pendidikan, arah dan tujuannya selanjutnya ditentukan oleh corak politik yang ditentukan oleh pemerintah.

Dengan demikian, campur tangan atau pengaruh pemerintah terhadap pendidikan ini cukup besar dengan segala kebijakan yang ditempuh demi suksesnya pendidikan seluruh warga negara.

\section{B. Kebijakan Pemerintah dalam Teori}

Banyak definisi tentang konsep kebijakan. Thomas Dye memberi batasan atas kebijakan sebagai “... apa saja yang hendak dilaksanakan atau tidak dilaksanakan oleh pemerintah."1 Richard Hofferbert mendefinisikan sebagai “...produk-produk yang kelihatan dari keputusan-keputusan yang diambil oleh tokoh-tokoh yang dapat mengidentifikasikan diri dengan cita-cita masyarakat."2 Banyak peneliti lain berpendapat bahwa tidak mungkin memberikan satu definisi saja atas kebijakan. Mereka yakin bahwa perlu mendaftarkan berbagai elemen dan pengertian-pengertian lain mengenai kebijakan, seperti tujuan-tujuan dan implementasi program-program, atau pemikiran-pemikiran sebagai bermacam-macam aspek keuntungan langsung dan tidak langsung serta biaya kebijakan. ${ }^{3}$

Agak berbeda dengan definisi-definisi di atas, James Anderson mendefinisikan kebijakan sebagai "suatu pola tingkah laku yang terarah kepada tujuan yang diikuti oleh seseorang atau beberapa orang dalam menangani suatu masalah."4 Pola tingkah laku yang terarah kepada tujuan berhubungan dengan kenyataan bahwa kebijakan adalah sesuatu yang gelap dan abstrak yang mendorong kepada keputusan-keputusan selanjutnya.

Dalam Ensiklopedi Politika, kebijakan disebut dengan istilah "kebijaksanaan," yang dalam bahasa Inggris juga disebut dengan public policy, policy ataupun beleid. Yang dimaksud dengan kebijaksanaan adalah suatu kumpulan keputusan yang diambil oleh seorang pelaku atau oleh kelompok politik dalam usaha memilih tujuan-tujuan dan

\footnotetext{
${ }^{1}$ Thomas R. Dye, Understanding Public Policy, (Englewood Cliffs, New Jersey: Prentice Hall, 1978), hlm. 3

${ }^{2}$ Richard I. Hofferbert, The Study of Public Policy, (Indianapolis: Bobbs-Merrill, 1974), hlm. 4

${ }^{3}$ George C. Edward III dan Ira Sharkansky, The Policy Predicament: Making and Implementing Public Policy, (San Fransisco: WH. Freeman \& Co. Publisher, 1978), hlm. 2

${ }^{4}$ James E. Anderson, Public Policy Making, (New York: Holt, Rinehart \& Winston, 1979), hlm. 3
} 
cara-cara untuk mencapai tujuan itu. Pada umumnya, pihak yang membuat kebijaksanaan tersebut sekaligus mempunyai kekuasaan untuk melaksanakannya. ${ }^{5}$

Secara umum terdapat empat faktor yang mempengaruhi kebijakan, yaitu lingkungan, persepsi pembuat kebijakan mengenai lingkungan, aktivitas pemerintah perihal kebijakan, dan aktivitas masyarakat perihal kebijakan. ${ }^{6}$

Pengertian lingkungan dikelompokkan ke dalam tiga kategori. Pertama, lingkungan umum di luar pemerintahan dalam arti pola-pola yang melibatkan faktor sosial, ekonomi, politik, sistem kepercayaan, dan nilai-nilai, seperti pola pengangguran, pola-pola partisipasi politik, dan urbanisasi. Kedua, lingkungan di dalam pemerintah dalam arti struktural, seperti karakteristik birokratis, dan personil berbagai departemen dan karakteristik berbagai komisi, dan para anggota dalam badan perwakilan rakyat maupun dalam arti proses, seperti karakteristik pembuatan keputusan di berbagai departemen dan badan perwakilan rakyat. Ketiga, lingkungan khusus dari kebijakan tertentu. Suatu kebijakan akan dipengaruhi oleh kebijakan yang dibuat sebelumnya.

Ketiga jenis lingkungan ini secara sendiri atau bersama-sama kemungkinan akan mempengaruhi proses dan isi kebijakan. Selain itu, persepsi pembuat kebijakan yang akurat maupun yang tidak akurat atas lingkungan-lingkungan itu, termasuk atas berbagai peristiwa dan kecenderungan yang terjadi dalam pemerintahan maupun di luar pemerintah, juga ikut mempengaruhi kebijakan yang akan dibuat karena elit akan bertindak atas persepsi sendiri.

Aktivitas pemerintah yang menyangkut kebijakan bersifat saling mempengaruhi aktivitas masyarakat. Pemerintah berinteraksi dengan masyarakat dalam konteks lingkungan tertentu untuk menyusun kebijakan umum. Apa yang dilakukan pemerintah dalam bidang zakat turut ditentukan oleh apa yang dilakukan masyarakat dalam bidang zakat.

Aktivitas pemerintah yang menyangkut kebijakan meliputi dua hal. Pertama, sejumlah aktivitas dan proses yang menghasilkan suatu rumusan kebijakan (pernyataan mengenai tujuan yang hendak dicapai) yang menyangkut intern pemerintahan maupun yang menyangkut masyarakat umum. Kedua, pelaksanaan kebijakan yang mencakup

${ }^{5}$ Cheppy Hari Cahyono dan Suparlan Alhakim, Ensiklopedi Politika, (Surabaya: Usaha Nasional, 1982), hlm. 170

${ }^{6}$ Randal B. Ripley, Policy Analysis in Political Science, (Chicago: Nelson-Hal Publishers, 1985), hlm. 34-48 
upaya-upaya penyediaan sumberdaya bagi pelaksana kebijakan, membuat peraturan, dan petunjuk pelaksanaan, menyusun rencana detail kegiatan, pengorganisasian pelaksanaan, dan memberikan pelayanan dan kemanfaatan.

Di samping itu, aktivitas masyarakat yang berkaitan dengan kebijakan juga mencakup dua hal. Pertama, pemanfaatan kebijakan oleh masyarakat dalam arti siapa yang terlibat dalam pelaksanaan kebijakan dan siapa saja yang memetik manfaat dari kebijakan. Kedua, hasil program atau kebijakan dalam arti apa dampak kebijaksanaan terhadap masyarakat dan mengapa berdampak demikian.

Proses pembuatan dan pelaksanaan kebijakan dibagi menjadi empat tahap, yaitu politisasi suatu permasalahan (penyusunan agenda), perumusan, dan pengesahan tujuan dan program, pelaksaksanaan program, serta monitoring dan evaluasi pelaksanaan program. $^{7}$

Politisasi suatu permasalahan yang dihadapi masyarakat dapat dilakukan oleh pemerintah atau kalangan masyarakat seperti individu atau kelompok. Apabila upaya itu berasal dari masyarakat maka ia akan berwujud imbauan atau tuntutan agar pemerintah menaruh perhatian yang saksama terhadap permasalahan yang menjadi kepentingannya itu. Apabila mungkin juga menjadikannya sebagai program pemerintah. Tujuan pemasyarakatan ini untuk menggugah perhatian dan dukungan dari masyarakat luas pada umumnya, dan pemerintah pada khususnya. Apabila upaya datang dari pemerintah maka ia berwujud pernyataan tentang tekad pemerintah untuk menangani permasalahan tertentu.

Dalam kenyataan, tidak semua permasalahan yang sudah menjadi agenda pemerintah mendapat perlakuan detail yang sama dalam arti dijadikan kebijakan. Ketika suatu agenda digarap secara detail maka kegiatan-kegiatan yang menjadi tahap perumusan dan pengesahan harus dilakukan.

Pertama, sejumlah informasi perlu dikumpulkan, diolah dan didiskusikan sehingga ia tak hanya lengkap, tetapi juga akurat. Kedua, informasi yang lengkap dan akurat tidak hanya akan menghasilkan berbagai alternatif kebijakan (program-program) tetapi juga sebagian besar kemungkinan berdampak positif dan negatif setiap alternatif kebijakan dapat diperkirakan sehingga atas dasar itu dapat dipilih salah satu alternatif

\footnotetext{
${ }^{7}$ Ramlan Surbakti, Memahami Ilmu Politik, (Jakarta: Grasindo, 1999), hlm. 197-199
} 
untuk disahkan sebagai keputusan. Ketiga, menggalang kesatuan pendapat dan koalisi di antara berbagai individu atau kelompok yang mempunyai pandangan dan kepentingan yang berbeda. Keempat, diskusi, perdebatan, tawar-menawar, dan kompromi yang berhasil menelurkan kesepakatan.

Apabila upaya di atas gagal mencapai kesepakatan maka tidak ada keputuasan yang akan disahkan. Produk tahap kedua ini pernyataan kebijakan (yang biasanya berisi tujuan yang hendak dicapai) dan program-program kongkret yang dirancang untuk mencapai tujuan tersebut. Apabila kesepakatan dicapai dengan kompromi maka tujuan dan program-program itu dirumuskan secara umum dan abstrak. Makin kongkret dan spesifik suatu tujuan dan program maka makin sukar dicapai kesepakatan. Sebaliknya, apabila kesepakatan itu dicapai dengan suara bulat maka tujuan dan program akan dirumuskan secara kongkret dan spesifik. Faktor lain yang mempengaruhi spesifik atau tidaknya kebijakan tersebut, waktu yang tersedia untuk merumuskannya.

Apabila tujuan dan program-program kebijakan dirumuskan dan disahkan sebagai keputusan politik maka tibalah tahap pelaksanaan kebijakan. Tahap pelaksanaan kebijakan mencakup sejumlah kegiatan. Pertama, menyediakan sumberdaya (anggaran, personil, dan sarana) bagi pelaksanaan kebijakan. Kedua, melakukan interprestasi dan penjabaran kebijakan dalam bentuk peraturan pelaksanaan dan petunjuk pelaksanaan. Ketiga, menyusun rencana sejumlah langkah kegiatan pelaksanaan menurut waktu, tempat, situasi, dan anggaran. Keempat, pengorganisasian secara rutin atas personil, anggaran, dan sarana materiil lainnya. Kelima, memberikan manfaat kepada dan/atau pengenaan beban dan pengaturan perilaku terhdap individu, dan masyarakat pada umumnya. Sebagai akibat pelaksanaan kegiatan-kegiatan ini sejumlah pihak yang tidak kebagian manfaat, atau menanggung beban yang dianggapnya tidak adil, ataupun dikenakan pembatasan ruang gerak yang dianggap melanggar hak asasi mungkin akan kecewa dan frustasi sehingga menimbulkan konflik dengan pemerintah. Sejumlah langkah integrasi perlu ditempuh oleh pemerintah.

Pemantauan (monitoring) dan evaluasi pelaksanaan kebijakan merupakan tahap terakhir dari proses pembuatan dan pelaksanaan kebijakan. Pemantauan atas kegiatan pelaksanaan kebijakan bertujuan untuk secepat mungkin memperbaiki setiap kekeliruan yang terjadi dalam pelaksanaan sehingga tujuan kebijakan dapat dicapai. Evaluasi atas 
pelaksanaan kebijakan biasanya dilakukan setelah kebijakan selesai dilaksanakan. Evaluasi diarahkan pada kegiatan pelaksanaan dan hasil pelaksanaan (manfaat dan dampaknya). Pertanyaan yag hendak dijawab dalam tahap ini, apakah dampak kebijakan tersebut bagi masyarakat, seberapa besar keberhasilan kebijakan itu dilaksanakan, dan mengapa demikian? Evaluasi atas pelaksanaan kebijakan itu tak hanya bertujuan untuk mengetahui apakah tujuan kebijakan tercapai atau tidak, tetapi juga untuk mendapatkan masukan bagi penyusunan kebijakan berikutnya, bahkan sebagai masukan dalam pengambilan keputusan masa depan program tersebut.

\section{Kebijakan Pemerintah terhadap Pendidikan pada Masa Orde Baru dan Orde}

\section{Lama}

Setelah Proklamasi Kemerdekaan Indonesia tanggal 17 Agustus 1945, maka perubahan-perubahan tidak hanya terjadi dalam bidang pemerintahan, tetapi juga dalam bidang pemerintahan saja, tetapi juga dalam bidang pendidikan. Perubahan yang terjadi dalam bidang pendidikan merupakan perubahan yang bersifat mendasar, yaitu perubahan menyangkut penyesuaian kebijakan pendidikan dengan dasar dan cita-cita dari suatu bangsa yang merdeka dan negara yang merdeka. Untuk mengadakan penyesuaian dengan cita-cita bangsa Indonesia yang merdeka itulah maka pendidikan mengalami perubahan terutama dalam landasan idiilnya, tujuan pendidikan, sistem persekolahan, dan kesempatan belajar yang diberikan kepada rakyat Indonesia. ${ }^{8}$

Pancasila sebagai dasar dan falsafah negara Indonesia sebagaimana tertera dalam Pembukaan Undang-Undang Dasar 1945 kemudian dijadikan landasan idiil pendidikan di Indonesia. Walaupun dalam kurun waktu 1945-1950 negara Indonesia mengalami beberapa kali perubahan Undang-Undang Dasar, tetapi dasar falsafah negara tidak mengalami perubahan. Karena itulah Pancasila mantap menjadi landasan idiil pendidikan di Indonesia. ${ }^{9}$

Meskipun Indonesia baru memproklamirkan kemerdekaannya dan tengah menghadapi revolusi fisik, pemerintah Indonesia sudah berbenah diri terutama

\footnotetext{
${ }^{8}$ Ary H. Gunawan, Kebijakan-kebijakan Pendidikan di Indonesia, (Jakarta: Bina Aksara, 1986), hlm. 32

9 Sumarsono Mestoko, et.al., Pendidikan di Indonesia dari Zaman ke Zaman, (Jakarta: Balai Pustaka, 1985), hlm. 145-147
} 
memperhatikan masalah pendidikan yang dianggap cukup vital dan menentukan, untuk itu dibentuklah Kementerian Pendidikan Pengajaran dan Kebudayaan (PP dan K). Dengan terbentuknya Kementerian Pendidikan tersebut maka diadakanlah berbagai usaha, terutama mengubah sistem pendidikan dan menyesuaikannya dengan keadaan yang baru.

Menteri Pendidikan Pengajaran dan Kebudayaan (PP dan K) pertama Ki Hajar Dewantara mengeluarkan Instruksi Umum yang isinya memrintahkan kepada semua kepala-kepala sekolah dan guru-guru, yaitu:

1. Mengibarkan Sang Merah Putih tiap-tiap hari di halaman sekolah.

2. Melagukan lagu kebangsaan Indonesia Raya.

3. Menghentikan pengibaran bendera Jepang dan menghapuskan nyanyian Kimigayo lagu kebangsaan Jepang.

4. Menghapuskan pelajaran bahasa Jepang, serta segala upacara yang berasal dari pemerintah balatentara Jepang.

5. Memberi semangat kebangsaan kepada semua murid. ${ }^{10}$

Tindakan pertama yang diambil oleh pemerintah Indonesia ialah menyesuaikan pendidikan dengan tuntutan dan aspirasi rakyat, sebagaimana tercantum dalam UUD 1945 pasal 31 yang berbunyi:

1. Tiap-tiap warga negara berhak mendapat pengajaran.

2. Pemerintah mengusahakan suatu sistem pengajaran nasional yang diatur dengan undang-undang. ${ }^{11}$

Oleh sebab itu, pembatasan pemberian pendidikan disebabkan perbedaan agama, sosial, ekonomi dan golongan yang ada di masyarakat tidak dikenal lagi. Dengan demikian, setiap anak Indonesia dapat memilih kemana dia akan belajar, sesuai dengan kemampuan, bakat dan minatnya. ${ }^{12}$

Pada periode Orde Lama ini berbagai peristiwa dialami oleh bangsa Indonesia dalam dunia pendidikan, yaitu:

1. Dari tahun 1945-1950 landasan idiil pendidikan adalah UUD 1945 dan falsafah Pancasila,

\footnotetext{
${ }^{10}$ I. Djumhur-Danasaputra, Sejarah Pendidikan, (Bandung: CV. Ilmu, 1979), hlm. 200

${ }^{11}$ Endang Sudardja, UUD RI '45 dalam Hubungannya dengan Pendidikan Moral Pancasila, (Bandung: Ghalia Indonesia, 1984), hlm. 89

${ }_{12}$ Zahara Idris, Dasar-dasar Kependidikan, (Bandung: Angkasa, 1981), halm. 30
} 
2. Pada permulaan tahun 1949 dengan terbentuknya Negara Republik Indonesia Serikat, di negara bagian timur dianut suatu sistem pendidikan yang diwarisi dari zaman pemerintahan Belanda.

3. Pada tanggal 17 Agustus 1950, dengan terbentuknya kembali Negara Kesatuan RI, landasan idiil pendidikan UUDS RI.

4. Pada tahun 1959 Presiden mendekritkan RI kembali ke UUD 1945 dan menetapkan Manifesto Politik RI menjadi Haluan Negara. Di bidang pendidikan ditetapkan Sapta Usaha Tama dan Panca Wardhana.

5. Pada tahun 1965, sesudah peristiwa G 30 S/PKI kita kembali lagi melaksanakan Pancasila dan UUD 1945 secara murni dan konsekuen. ${ }^{13}$

Selain itu Belanda juga sangat mencurigai dan tidak suka terhadap keberadaan pendidikan Islam yang diselenggarakan di pesantren-pesantren, madrasah-madrasah dan sebagainya. Hal ini disebabkan, karena lembaga pendidikan Islam tersebut dianggap sarang pemberontakan dan pembangkang dan sebagainya. Diketahui bahwa di dalam Islam terdapat konsep jihad, yakni perang melawan orang-orang kafir; dan Belanda dianggap sebagai orang kafir yang harus diperangi. Dalam keadaan demikian, maka politik pendidikan yang diterapkan oleh umat Islam adalah bersikap non-kooperatif, yakni tidak mau bekerja sama dengan pemerintah Belanda, dan bercita-cita untuk mengusir Belanda dengan mendorong para pelajar untuk berjuang perang melawan Belanda. Sejalan dengan itu, bangsa Indonesia, khususnya umat Islam mulai meyelenggarakan kegiatan pendidikan dengan sistem sekolah sebagaimana diterapkan oleh Belanda. Kegiatan pendidikan ini dilaksanakan oleh organisasi-organisasi Islam seperti Muhammadiyah, Nahdlatul Ulama, Persatuan Islam, dan sebagainya. Di lembaga-lembaga pendidikan Islam tersebut selain diberikan pengetahuan agama juga diberikan pengetahuan umum, rasa cinta tanah air (nasionalisme), semangat kejuangan dan membela kebenaran (patriotismse) melalui pendidikan kepanduan, nyanyian dan lain sebagainya. Dari lembaga pendidikan inilah selanjutnya dilahirkan Sumpah Pemuda, yang selanjutnya timbul semangat untuk berjuang mengusir penjajah.

Dengan demikian, politik pendidikan Islam yang dilakukan pada masa Prakemerdekaan amat dipengaruhi oleh politik dan kebijakan pemerintah pada masa itu,

\footnotetext{
${ }^{13}$ Ibid., hlm. 31
} 
yakni pemerintah kolonialis Belanda. Politik pendidikan Islam yang diterapkan tokohtokoh pendidikan Islam tentang perlunya melakukan pembaharuan pendidikan Islam, juga ternyata telah berjasa dalam melahirkan kader-kader pemimpin bangsa yang berjiwa nasionalis, patriotis dan keperibadian Indonesia.

Politik pendidikan Islam yang diterapkan tokoh-tokoh pendidikan Islam pada masa itu, selain telah menyadarkan umat Islam tentang perlunya melakukan pembaharuan pendidikan Islam, juga ternyata telah melakukan pembaharuan pendidikan Islam, juga ternyata telah berjasa dalam melahirkan kader-kader pemimpin bangsa yang berjiwa nasionalis, patriotis dan berkepribadian Indonesia.

Politik pendidikan Islam sebagimana disebutkan di atas berbeda dengan politik pendidikan Islam yang diterapkan pada masa pasca-kemerdekaan di zaman Orde Lama. Pada masa ini politik pendidikan Islam lebih diarahkan pada upaya memperbaharui dan memperbanyak lembaga pendidikan Islam yang lebih bermutu sejalan dengan tutuntutan zaman. Namun keinginan ini belum terlaksana sepenuhnya, mengingat Indonesia yang baru saja merdeka masih berada dalam keadaan panca-roba dan mencari bentuk yang sesungguhnya. Selain itu adanya kekuatan ideologis yang mempengaruhi situasi politik dan kebijakan pemerintah juga ikut serta mempengaruhi politik pendidikan Islam pada itu. Pemerintah juga ikut serta mempengaruhi politik pendidikan Islam pada itu. Pemerintah Orde Lama berada dalam tarikan tiga kekuatan, yaitu nasionalis, sekularis-komunis dan Islamis. Tiga kekuatan ideologis ini sering kali berbenturan, dan saling mengalahkan sejarah mencatat, bahwa Presiden Soekarno menganut paham ideologi nasionalis yang berbasis pada ke-Indonesiaan dan kultural. Dalam posisi ini ia terkadang dekat kepada kelompok Islam dan terkadang dekat pada kelompok sekularis-komunis. Menjelang akhir tahun 60-an misalnya, Soekarno lebih banyak terjebak ke dalam perangkap kaum sekuler-komunis, sampai akhirnya ia dituduh berada di belakang Gerakan 30 S-PKI. Dalam keadaan demikian, perhatian Soekarno terhadap pendidikan Islam amat kurang, bahkan umat Islam terpinggirkan, dan banyak sekali tokoh-tokoh Muslim yang dipenjarakan. Dengan demikian, politik pendidikan Islam lebih diarahkan pada upaya membendung paham komunis.

Selanjutnya keadaan tersebut berbeda dengan politik pendidikan Islam pada masa Orde Baru yang dimulai tahun 1966. Pada awalnya umat Islam amat berharap 
kepada Pemerintahan Orde Baru agar memperhatikan nasib pendidikan Islam. Namun harapan ini juga belum terwujud sebagai akibat dari kebijakan politik Pemerintahan Orde Baru yang terkadang kurang sejalan dengan keinginan umat Islam.

Ada beberapa karakteristik Pemerintah Orde Baru yang kurang kondusif bagi pengembangan pendidikan Islam. Dalam hubungan ini paling kurang ada lima karakteristik Pemerintahan Orde Baru. Pertama, Pemerintahan Orde baru adalah pemerintahan yang kuat dan dominan; kedua, Pemerintah Orde Baru adalah pemerintahan yang dipimpin serta didukung oleh kekuatan militer yang bekerjasama dengan teknokrat dan birokrat sipil; ${ }^{14}$ ketiga, Pemerintah Orde Baru melengkapi dirinya dengan aparat keamanan represif serta aparat politik-ideologis untuk melerestarikan dan memproduksi kekuatannya; keempat, Pemerintah Orde Baru sejak awal kebangkitannya mendapatkan dukungan dari kapitalisme internasional; dan kelima, jika pada suatu saat Pemerintah Orde Baru mengalami instabilitas, maka hal ini terjadi bukan karena menguatnya posisi politik masyarakat, melainkan lebih disebabkan oleh faktor dari dalam tubuh negara sendiri dan faktor dunia internasional.

Karakteristik Pemerintah Orde Baru yang demikian itulah yang pada akhirnya menjadikan masyarakat sangat tumpul dan lemah baik dalam bidang politik, ekonomi, sosial, bahkan budaya apalagi dalam bidang-bidang keamanan. Masyarakat tidak memiliki nilai bargaining yang cukup kuat di hadapan pemerintah. Masyarakat seakan dikebiri dalam berbagai aktivitasnya. Pemikiran-pemikiran masyarakat kurang berkembang khususnya yang agak sedikit berbeda dengan ideologi atau paham pemerintah.

Oleh karena itu masyarakat yang hidup pada masa Orde Baru memiliki karakteristik seperti berikut. Pertama, masyarakat Orde Baru mempunyai kedudukan yang lemah jika berhadapan dengan kekuasaan pemerintah; kedua, masyarakat Orde Baru adalah masyarakat yang disartikulatif dan involutif; ${ }^{15}$ ketiga, masyarakat Orde

14 Lihat, A.S. Hikam, Politik Kewarganegaraan Landasan Redemokratisasi di Indonesia, (Jakarta: Erlangga, 1999) hlm.3-4. Lihat pula Dewi Portuna Anwar, "Format Politik Orde Baru dan Agenda Pengembangan Demokrasi Politik" dalam Syarofin Arba MF., (ed), Demitologisasi Politik Indonesia Mengusung Elitisme Orde Baru, (Jakarta: PT. Pustaka Grasindo, 1998), hlm. 4-6

15 Disartikulatif adalah masyarakat yang tidak mampu mengartikulasikan dirinya ke dalam kekuatan politik, ekonomi, hukum atau lainnya sehingga ia dapat terlibat lebih jauh bersama-sama pemerintah. Involutif adalah masyarakat yang tidak mampu mengekpresikan ide, harapan, kehendak, tuntutan tentang demokrasi, keadilan, pemerataan, dan hak asasi manusia dalam realitas politik, ekonomi, 
Baru adalah masyarakat yang mengalami fragmentasi baik yang bersifat cultural maupun struktural. ${ }^{16}$

Sebagai akibat dari Pemerintahan Orde baru yang mempunyai karakteristik sebagaimana tersebut di atas (kuat, dominan, repressif dan militeris) dan masyarakat yang berciri sebaliknya (lemah, tidak berperan fragmentatif, ketakutan, disarkulatif dan inovatif), maka hubungan yang terjadi antara pemerintah dan rakyat adalah bukan hubungan yang harmonis dalam arti yang sebenarnya (pseudo harmonis). Situasi dan kondisi yang tampak stabil sebenarnya menyimpan bara instabilitas yang tinggi. Hubungan yang terjadi bersifat konspiratif, kooptatif dan dominatif. ${ }^{17}$

Dari uraian tersebut di atas dapat dipahami munculnya fenomena yang sangat kontradiktif dan kontraversial. Fenomena tersebut adalah terjadinya perbedaan yang cukup mencolok antara kebijakan politik pemerintah secara teoritis yang bersifat formal konstitusional dengan implementasi yang bersifat represif dominatif. Kebijakan politik pemerintah yang berupa peraturan perundingan selama masa Orde Baru bukannya meningkatkan perundingan selama masa Orde Baru bukannya meningkatkan pemerdayaan masyarakat di bidang politik, akan tetapi malah sebaliknya mengkerdilkan aspirasi dan aktivitas politik masyarakat sehingga menjadi tidak berdaya sama sekali.

hukum atau lainnya. Masyarakat tersebut hanya berputar-putar pada tingkat retorika dan kata-kata belaka. Lihat Farchan Bulkin, Nasib Publik dalam Sebuah Republik, dalam Prisma, No. 8 LP3S, 1985, Jakarta, hlm. 23-36

${ }^{16}$ Akhmad Zaini Abar, Kisah-kisah Pers Indonesia, 1966-1974, (Yogyakarta: LkiS, 1995), hlm. 220

${ }^{17}$ Hubungan yang bersifat konspriratif adalah hubungan antara pemerintah dan masyarakat yang terjadi karena adanya kepentingan dan keprihatinan bersama tentang berbagai krisis politik, ekonomi, hokum atau lainnya yang terjadi pada saat itu. Hal ini dapat dilihat pada masa awal Orde Baru yang sedang menghadapi krisis ekonomi dan politik. Sedangkan hubungan yang bersifat kooptatif adalah hubungan antara pemerintah dan masyarakat yang terjadi karena terjadinya berbagai penertiban unsurunsur masyarakat oleh pemerintah. Penertiban tersebut dilaksanakan dengan dua cara. Pertama, dengan cara melakukan intervensi terhadap urusan-urusan intern organisasi sosial politik, sosial kemasyarakatan atau sosial keagamaan. Kedua, dengan cara menciptakan wadah baru untuk menggantikan wadah-wadah lama yang sudah ada atau pun untuk mewadahi unsur-unsur masyarakat yang belum punya wadah. Hal ini dapat dilihat dengan penertiban partai politik, pers, aktivitas kemahasiswaan, dan organisasi sosial lainnya. Selanjutnya hubungan yang bersifat dominatif adalah hubungan antara pemerintah dan masyarakat yang terjadi bilamana pemerintah melakukan penertiban yang bersifat memaksa terhadap sekelompok atau unsur masyarakat yang jelas-jelas berbeda dengan kebijakannya, baik dalam hal pemikiran, perencanaan, implementasi maupun tujuan pembangunan. Hal ini dilakukan karena pemerintah Orde Baru dipimpin dan didukung oleh aparat militer yang menjadi salah satu dari tiga pilar pemerintah, di samping Golongan Karya dan Birokrasi. Lihat Syaifi Ai Anwar, Pemikiran dan Aksi Islam di Indonesi: Sebuah Kajian Politik tentang Cendikiawan Muslim Orde Baru, (Jakarta: Paramadina, 1995), hlm. 75-81; lihat pula Ignas Kleden," Politik Teknokrasi” dalam Prisma No. 3 Tahun 1983, h. 2330; Alfian, Pemikiran dan Perubahan Politik Indonesia, (Jakarta: Gramedia, 1992), hlm. 30-32; B.J Bolland, The Struggle of Islam in Modern Indonesia, (The Hague: Martinus Nojhoff. 1971), hlm. 135-148 
Berdasarkan pada konsep politik yang diterapkan seperti, maka politik pendidikan pada masa Pemerintahan Orde Baru mengacu kepada Garis-garis Besar Haluan Negara yang mulai diberlakukan sejak tahun 1973. Sedangkan pada awal Orde Baru berdasarkan Ketetapan MPRS No. XXVII/MPRS/1966 yang secara umum tujuan pendidikan pada masa Orde Baru adalah untuk membantu manusia yang berjiwa Pancasila, cerdas, terampil dan berbudi pekerti luhur serta berkepribadian Indonesia yang bertanggung jawab terhadap pelaksanaan pembangunan. ${ }^{18}$

Permasalahan yang dihadapi pemerintah Orde Baru dalam bidang pendidikan di antaranya adalah masalah pemerataan, peningkatan kualitas, efektifitas dan efisiensi, dan relevansi pendidikan dengan pembangunan nasional. Keempat permasalahan ini oleh pemerintah Orde Baru ditangani dan diselesaikan dengan berbagai upaya yang selanjutnya dikenal dengan kebijakan pendidikan.

Kebijakan pendidikan tersebut adalah pertama, melanjutkan program pemberantasan buta huruf yang pada tahun 1972 dikembangkan lebih lanjut dengan memberikan keterampilan tertentu; kedua, melaksanakan pendidikan masyarakat agat memiliki kemampuan mental, spiritual, serta keterampilan; ketiga, mengenalkan pendidikan luar sekolah yang berorientasi kepada hal-hal penting yang berkaitan dengan kehidupan sosial, ekonomi dan budaya sebagai kebutuhan praktis; keempat, mengenalkan kegiatan inovasi pendidikan, misalnya Kuliah Kerja Nyata (KKN), dibukanya sekolah dan universitas terbuka, wajib belajar, dan sebagainya; kelima, pembinaan generasi muda melalui Organisasi Siswa Intra Sekolah (OSIS), Organisasi Mahasiswa Kampus, Komite Nasional Pemuda Indonesia (KNPI), atau organisasi kepemudaan lainnya; keenam, dilaksanakannya program orang tua asuh mulai tahun 1984. ${ }^{19}$

Kebijakan pendidikan pemerintah Orde Baru semakin jelas terlihat ketika dikeluarkannya Undang-Undang Nomor 2 Tahun 1989 tentang Sistem Pendidikan Nasional. Seluruh sistem pendidikan yang ada di Indonesia harus mengacu kepada undang-undang tersebut, bagaimanapun bentuk dan kondisinya.

\footnotetext{
${ }^{18}$ Lihat Hasbullah, Sejarah Pendidikan Islam di Indonesia: Lintasan Sejarah Pertumbuhan dan Perkembangan, (Jakarta: PT. RajaGrafindo Persada, 1985), hlm. 81-82 hlm. 51

19 Ary H. Gunawan, Kebijakan-kebijakan Pendidikan di Indonesia, (Jakarta: Bina Aksara, 1986),
} 
Upaya-upaya di atas merupakan kebijakan pendidikan pemerintah Orde Baru yang dicanangkan secara nasional. Namun demikian, dalam realisasinya kebijakan pendidikan tersebut mengarahkan pada satu tujuan untuk memperkuat hegemoni pemerintah Orde Baru di hadapan masyarakat. ${ }^{20}$ Alokasi dana dalam Anggaran Pendapatan Belanja Negara (APBN) yang sangat minim dalam bidang pendidikan menjadikan pendidikan sebagai sektor yang sangat lemah dan terasa sulit untuk mengatasi berbagai permasalahan yang dihadapi. Meskipun sudah diatur dalam Pasal 36 UUSPN No. 2 Tahun 1989 tersebut, tetapi tidak mampu memberi solusi yang konkrit terhadap persoalan dalam bidang pendidikan.

Apabila politik pendidikan yang diambil oleh pemerintah Orde Baru dikaji lebih jauh, maka akan tampak karakteristik yang hampir sama dengan kebijakan sosial politiknya. Di antara karakteristik yang dapat dilihat adalah sentralistik, depolitisasi masyarakat, penguatan kekuasaan pemerintah dan terkesan kurang serius. Walaupun dalam undang-undang itu tidak secara tegas dinyatakan karakteristik sentralisitik tersebut, namun pada pasal demi pasal dapat dilihat tidak adanya pelibatan pemerintah daerah dan lembaga pendidikan untuk menentukan kebijakan yang berkaitan dengan pelaksanaan pendidikan.

Sehubungan dengan hal di atas, pemerintahan Orde Baru menggiring politik pendidikannya kepada sistem sentralistik. ${ }^{21}$ Sistem sentralistik menjadi kebijakan pendidikan utama dalam Pemerintahan Orde Baru. Politik pendidikan yang bersifat sentralistik akan memudahkan pemerintah untuk memonitor dan mengontrol jalannya penyelenggaraan pendidikan. Karena Pemerintahan Orde Baru menyadari bahwa pendidikan adalah sarana yang paling strategis dalam meningkatkan pemberdayaan masyarakat di berbagai bidang. Agar pemeberdayaan masyarakat melalui pendidikan mengarah pada sasaran dan tujuan menurut pemerintah, maka segala perencanaan pendidikan harus ditentukan dan dikontrol oleh pusat.

Selain itu Pemerintah Orde Baru juga berupaya menggiring politik pendidikannya pada upaya depolitisasi masyarakat. Berbagai kebijakan yang diambil

20 Dalam upaya menganalisis kebijakan pendidikan terdapat tiga teori, yaitu teori fungsionalisme, teori human capital, dan teori emperisme. Lihat Ace Suryadi dan H. A. R. Tilaar, Analisis Kebijakan Pendidikan: Suatu Pengantar, (Bandung: PT. Remaja Rosdakarya, 1994), hlm. 19-27

${ }^{21}$ Mastuhu,"Pendidikan Indonesia Menyongsong Indonesia Baru Pasca Orde Baru" dalam Gema Jurnal Pendidikan dan Kebudayaan, Edisi 1 Agustus, Jakarta, 1995, hlm. 17 -19 
pemerintah Orde Baru mengarah kepada pengkerdilan aspirasi politik masyarakat khususnya mahasiswa. Dalam struktur organisasi kemahasiswaan tidak diperkenankan adanya unit kegiatan mahasiswa yang menjadi wadah aktivitas pilotik secara praktis dalam Perguruan Tinggi. Mahasiswa tidak diperkenankan berpolitik praktis dikampusnya. Normalisasi Kegiatan Kampus (NKK) dan Badan Kegiatan Kemahasiswaan (BKK) adalah senjata yang sangat ampuh untuk meredam meningkatkan pemeberdayaan politik mahasiswa. ${ }^{22}$

Selanjutnya Pemerintah Orde Baru juga mengarahkan politik pendidikannya pada penguatan kekuasaan pemerintah atau negara. Dalam kaitan ini semua pegawai negeri yang berkecimpung di bidang pendidikan tidak diperkenankan untuk menjadi anggota partai politik tertentu. Kebijakan ini menyebabkan para penyelenggaraan pendidikan hanya memiliki satu orientasi saja, yaitu loyalitas terhadap pemerintah. Berbagai pemikiran dan penelitian yang dilakukan harus mendukung atau paling tidak harus selaras dengan kebijakan pemerintah. Kebijakan yang demikian itu jelas hanya akan mengarah pada penguatan dan pelanggengan kekuasaan pemerintah Orde Baru. ${ }^{23}$

Dalam pada itu politik Pemerintah Orde Baru terlihat juga pada kurang perhatinnya terhadap pembiayaan. Anggaran belanja pemerintah yang dialokasikan dalam sektor pendidikan sangat minim, bila dibandingkan dengan negara-negara berkembang lainnya, apalagi jika hal itu dibandingkan dengan negara maju. Bila pemerintah benar-benar ingin meningkatkan kualitas sumber daya manusia Indonesia, maka biaya dan anggaran dalam sektor pendidikan mestinya diprioritaskan. Sebagaimana diketahui bahwa selama pemerintahan Orde baru anggaran sektor pendidikan tidak pernah mencapai apalagi melebihi 10\% dari Anggaran Pendapatan Belanja Negara (APBN) yang ditetapkan.

Dengan mengikuti uraian tersebut di atas terlihat bahwa politik pendidikan pemerintah Orde Baru tidak jauh berbeda dengan kebijakan politiknya bila kebijakan di bidang politik ini sangat melemahkan posisi umat Islam, maka politik pendidikan yang

22 Azyumardi Azra, "Kelompok Sempalan di Kalangan Mahasiswa PTU: Anatomi SosioHistoris" dalam Fuaduddin \& Cik Hasan Basri, Dinamika Pemikiran Islam di Perguruan Tinggi: Wacana tentang Pendidikan Agama Islam, (Jakarta: Logos Wacana Ilmu, 1999), hlm. 225

${ }^{23}$ Lihat Moh. Mahfud M.D., dkk., "Perspektif Politik dan Hukum tentang Kebebasan Akademi dan Kritik Sosial" dalam Moh. Mahfud M.D., dkk., Kritik Sosial dalam Wacana Pembangunan, (Yogyakarta: UII Press, 1999), hlm. 64-66 
ditempuh juga sama. Dengan demikian, terlihat bahwa kebijakan politik suatu negara akan sangat mempengaruhi politik pendidikannya.

Berdasar pada kondisi perpolitikan pemerintah sebagaimana tersebut di atas, tampak bahwa pendidikan Islam dalam perjalananya mengalami berbagai hambatan, tantangan, dan harapan, sepanjang sejarahnya pendidikan Islam senantiasa mengawal dan mengiringi perjalanan pendidikan nasional. Pendidikan Islam terus berproses bersama dengan pendidikan nasional untuk mengisi kemerdekaan dengan pembangunan dalam berbagai bidang.

\section{Penutup}

Peta politik Islam di Indonesia senantiasa diwarnai oleh peta perpolitikan pemerintah. Dari sejak zaman pra-kemerdekaan, pasca kemerdekaan (orde lama), orde baru dan era reformasi. Pendidikan Islam masih berada dalam posisi yang secara umum belum berpihak pada pemberdayaan umat. Pendidikan lebih merupakan alat untuk mana pemerintah menggunakannya untuk mengiring rakyat dan umat kepada tujuan politik yang diinginkan secara teoritis tidaklah salah jika pemerintah menginginkan agar produk lulusan lembaga pendidikan memberikan konstribusi bagi pembangunan. Namun pada saat yang sama seharusnya pemerintah juga memberikan kebebasan kepada dunia pendidikan untuk menentukan arahnya dengan tetap memperoleh bantuan, dukungan dan fasilitas dari pemerintah.

\section{E. Daftar Kepustakaan}

Ace Suryadi dan H. A. R. Tilaar, Analisis Kebijakan Pendidikan: Suatu Pengantar, Bandung: PT. Remaja Rosdakarya, 1994

Akhmad Zaini Abar, Kisah-kisah Pers Indonesia, 1966-1974, Yogyakarta: LkiS, 1995

Alfian, Pemikiran dan Perubahan Politik Indonesia, Jakarta: Gramedia, 1992

Ary H. Gunawan, Kebijakan-kebijakan Pendidikan di Indonesia, Jakarta: Bina Aksara, 1986

Ary H. Gunawan, Kebijakan-kebijakan Pendidikan di Indonesia, Jakarta: Bina Aksara, 1986

A.S. Hikam, Politik Kewarganegaraan Landasan Redemokratisasi di Indonesia, Jakarta: Erlangga, 1999 
Azyumardi Azra, "Kelompok Sempalan di Kalangan Mahasiswa PTU: Anatomi SosioHistoris" dalam Fuaduddin \& Cik Hasan Basri, Dinamika Pemikiran Islam di Perguruan Tinggi: Wacana tentang Pendidikan Agama Islam, Jakarta: Logos Wacana Ilmu, 1999

B.J. Bolland, The Struggle of Islam in Modern Indonesia, The Hague: Martinus Nojhoff. 1971

Cheppy Hari Cahyono dan Suparlan Alhakim, Ensiklopedi Politika, Surabaya: Usaha Nasional, 1982

Dewi Portuna Anwar, "Format Politik Orde Baru dan Agenda Pengembangan Demokrasi Politik" dalam Syarofin Arba MF., (ed), Demitologisasi Politik Indonesia Mengusung Elitisme Orde Baru, Jakarta: PT. Pustaka Grasindo, 1998

Endang Sudardja, UUD RI '45 dalam Hubungannya dengan Pendidikan Moral Pancasila, Bandung: Ghalia Indonesia, 1984

Farchan Bulkin, "Nasib Publik dalam Sebuah Republik," dalam Prisma, No. 8 LP3S, 1985, Jakarta

George C. Edward III dan Ira Sharkansky, The Policy Predicament: Making and Implementing Public Policy, San Fransisco: WH. Freeman \& Co. Publisher, 1978

Hasbullah, Sejarah Pendidikan Islam di Indonesia: Lintasan Sejarah Pertumbuhan dan Perkembangan, Jakarta: PT. RajaGrafindo Persada, 1985

I. Djumhur-Danasaputra, Sejarah Pendidikan, Bandung: CV. Ilmu, 1979

Ignas Kleden,” Politik Teknokrasi” dalam Prisma No. 3 Tahun 1983

James E. Anderson, Public Policy Making, New York: Holt, Rinehart \& Winston, 1979

Mastuhu,"Pendidikan Indonesia Menyongsong Indonesia Baru Pasca Orde Baru” dalam Gema Jurnal Pendidikan dan Kebudayaan, Edisi 1 Agustus, Jakarta, 1995

Moh. Mahfud M.D., dkk., "Perspektif Politik dan Hukum tentang Kebebasan Akademi dan Kritik Sosial" dalam Moh. Mahfud M.D., dkk., Kritik Sosial dalam Wacana Pembangunan, Yogyakarta: UII Press, 1999

Ramlan Surbakti, Memahami Ilmu Politik, Jakarta: Grasindo, 1999

Randal B. Ripley, Policy Analysis in Political Science, Chicago: Nelson-Hal Publishers, 1985

Richard I. Hofferbert, The Study of Public Policy, Indianapolis: Bobbs-Merrill, 1974

Sumarsono Mestoko, et.al., Pendidikan di Indonesia dari Zaman ke Zaman, Jakarta: Balai Pustaka, 1985

Syafi'i Anwar, Pemikiran dan Aksi Islam di Indonesi: Sebuah Kajian Politik tentang Cendikiawan Muslim Orde Baru, Jakarta: Paramadina, 1995

Thomas R. Dye, Understanding Public Policy, Englewood Cliffs, New Jersey: Prentice Hall, 1978

Zahara Idris, Dasar-dasar Kependidikan, Bandung: Angkasa, 1981 